farms differed in the way labor was specialized and configured, reference to income did not identify them. Both income and years of agricultural experience are often used to characterize family farms. Our results indicate that these do not adequately account for differences among farms with regard to resource use.

\section{Conclusion}

Organizational theory contends that the organization's structure reflects the organization's strategy for managing differences in production. We selected two organizational variables — task specialization and configuration - to distinguish farm types. Using data on farms on the westside of the San Joaquin Valley we grouped farms into five organization types. We then applied an ANOVA to discrete and continuous measures of farm structure including acres farmed, labor use, gross income, type of ownership, and operator residency to determine whether farm types differed with regard to these characteristics.

Our results indicated that farm types identified through task specialization and configuration differed with regard to many structural characteristics. Those characteristics for which farms did not significantly differ were in many cases criteria for other classifications systems. In particular, differences in type of ownership, relationship of manager to owner, residency of operator, type of financing, and years of agricultural experience did not correspond to differences in organization type. Full- and part-time labor and years of computer use were the strongest measures of difference among the organizational classes we identified.

Organizational classifications which reflect differences in resource use may be the most appropriate to assess the impact of different farming systems on the environment and society. These classifications provide significant measures of differences between farms which use labor differently to balance the varying conditions of production. In addition, organization types provide a means for depoliticizing the discussion of farm structure which is presently mired in abstract notions of family versus corporate management. Organizational variables represent traits inherent to all production organizations and, consequently, can be used to classify all farms regardless of differences in production system, ownership, or location.

M. B. Campbell is Director, Management Systems Research, Sacramento; A. Dinar is Visiting Scholar, Department of Agricultural Economics, UC Davis.

This study was partially funded by the San Joaquin Valley Drainage Program, Sacramento, $C A$.

\title{
1991 INDEX
}

Following are articles appearing in California Agriculture, Volume 45, Numbers 1 through 6 , January through December 1991. Back issues may be purchased, while supplies last, at $\$ 2.00$ per copy (make checks payable to UC Regents).

ANIMAL AND AVIAN SCIENCES

Specific gravity: a better test of first-milk quality - Toenjes, Strasser, Bath May-Jun 23

\section{COOPERATIVE EXTENSION}

How California educators and CE County Directors view agricultural literacy programs - Braverman, Rilla Nov-Dec 4

Leaf removal in wine grapes: a case study in extending research to the field - Pence, Grieshop Nov-Dec28

\section{ECONOMICS, FARM MANAGEMENT}

Farmworker injury and illness: statistical guides to prevention - Sutter Nov-Dec 13

Low-input technology proves viable for limited-resource farmers in Salinas Valley - Altieri et. al. MarApr 20

New index measures returns to risk in crop production - Blank MayJun 36

Special report: International trade Free trade with Mexico: economic impacts Hinojosa-Ojeda, Robinson, Moulton Sept-Oct 5 How the FTA will affect California agriculture Hinojosa-Ojeda, Robinson, Moulton Sept-Oct 7

Free trade impacts: Mexico's tomato processing industry may gain - Moulton Sept-Oct 11 Imperial Valley holds advantage in alfalfa, wheat and cotton Gonzalez et al. Sept-Oct 15 At present, livestock production more favorable in Imperial Valley - Guerrero et al. Sept-Oct 18 Asparagus, broccoli production likely to shift to Mexicali Gonzalez et al. Sept-Oct 21 How asparagus imports affect U.S. prices, grower returns and total acreage - French, Willett Sept-Oct 24

Do American farmers have a future in the Hong Kong market? - Carter Sept-Oct 27

\section{ENVIRONMENT}

Keeping the valley green: a public policy challenge - Carter et al. MayJun 10
San Joaquin River salinity: 1991 projections compared to 1977 Kratzer, Grober Nov-Dec 24

Survey documents open burning in the San Joaquin Valley - Jenkins, Turn, Williams Jul-Aug 12

Trace elements limit potential for blending San Joaquin drainwater with canal water - Hanson et al. MarApr 17

\section{FIELD CROPS}

Blackeye bean root rot diseases identified - Erwin et al. Jul-Aug 27

Imposed drought stress has no long-term effect on established alfalfa Frate, Roberts, Marble MayJun 33

Irrigation uniformity and cotton yields in the San Joaquin Valley Wichelns, Oster Jan-Feb 13

Plastic mulch increases cotton yield, reduces need for preseason irrigation - Ferreres, Goldhamer May-Jun25

Triticale: an alternative cereal grain in broiler starter diets - Vohra et al. Sept-Oct 34

Wild oat competition in short-statured wheat - Cudney et al. JanFeb22

\section{FOOD AND CONSUMER SCIENCE}

A shoppers' survey: California nuts and produce, food quality, and food safety - Pastore, Bruhn JanFeb 25

Culinary herb use in Southern California restaurants - Brown JanFeb 4

How safe is "organic"? - Beall, et al. JulAug 9

Pesticides and food: How safe is "safe"? - Beall et al. Jul-Aug 4

Pesticides in food: major controversies Beall et al. Jul-Aug 6

The Estonian Turg and the California Certified Farmers' Market Sommer, Raudsepp JanFeb 16

FORESTRY AND RANGE SCIENCE

Despite landowner favor, oak groves likely to diminish in size and number - Schmidt Nov-Dec 16

European mistletoe continues to spread in Sonoma County Hawksworth, Scharpf, Marosy Nov-Dec 39 
South Sierra oak regeneration weak in sapling stage - Standiford et al. Mar-Apr 12

Water-efficient clover fixes soil nitrogen, provides winter forage crop Williams et al. Jul-Aug 30

\section{FRUITS AND NUTS}

California almond markets and reserve strategies analyzed - Alston, Sexton Jul-Aug 18

Effect of a topically applied whitener on sun damage to Granny Smith apples - Sibbett et al. JanFeb 9

Fall almond pruning has practical advantages, no adverse effects - Reil et al. May-Jun 18

How quality relates to price in California fresh peaches - Parker, Zilberman, Moulton Mar-Apr 14

Over-tree sprinkling reduces abnormal shapes in 'Bing' cherries Southwick et al. Jul-Aug 24

Owning harvest equipment versus custom hiring: the case of walnuts Blank, Klonsky, Norris Nov-Dec 33

Thinning Granny Smith apples chemically - Micke et al. Jan-Feb 30

\section{LANDSCAPING AND HORTICULTURE}

Aphid problems increase on ornamentals - Vehrs, Parrella Jan-Feb 28

Environmental horticulture: "growth" industry in California - Pittenger, Gibeault, Cockerham MayJun 15

How disinfectants compare in preventing transmission of fire blight Teviotdale, Wiley, Harper JulAug 21

How to reduce water use and maximize yields in greenhouse roses Tjosvold, Schulbach May-Jun 31

Stress-adapted landscapes save water, escape injury in drought Sachs Nov-Dec 19

Tests compare fungicides for control of rust on greenhouse carnations - Ferrin, Rohde Jul-Aug 16
PEST AND DISEASE MANAGEMENT, PESTICIDES

Controlling Russian wheat aphid in California - Stern, Orloff JanFeb 6

Deadly insect pest poses increased risk to north coast vineyards Granett et al Mar-Apr 30

Guthion-resistant parasite ready for implementation in walnuts Hoy, Cave, Caprio Sept-Oct 29

Imported parasite of greenhouse thrips established on avocado in California - McMurtry, Johnson, Newberger Nov-Dec 31

Imported wasp helps control southern green stink bug - Hoffmann et al. May-Jun 20

Study describes ash borer infestations, tests management method Bone, Koehler Sept-Oct 32

Treatment of destructive elm leaf beetle should be timed by temperature — Dreistadt et al. Mar-Apr 23

To control mealybugs, stop honeydewseeking ants - Phillips, Sherk Mar-Apr 26

Vaccinating grapevines against spider mites - Karban, English-Loeb, Verdegaal Jan-Feb 19

\section{SOILS, WATER, FERTILIZATION}

\section{AND WEATHER}

Can farmers use water more effectively? Reducing drainwater: Furrow vs. subsurface irrigation Fulton et al. Mar-Apr 4 Subsurface drip produced highest net return in Westlands area study - Smith, Oster, Phene Mar-Apr 8

Analysis: Demonstration projects compared - Smith, Oster Mar-Apr 11

Fertilizers produce more range forage in drought than normal yearsReit, Bailey May-Jun 28

Ground water is key to easing drought impacts - Howitt May-Jun 4
Implementing CIMIS at the farm level: a grower's experience in walnuts - Fulton, Beede, Phene SeptOct 38

Liquid polymers keep drip irrigation lines from clogging - Meyer et al. Jan-Feb 24

'Well set aside' proposal: a scenario for ground water banking - Howitt, M'Marete May-Jun 6

\section{VEGETABLES}

Drip system design, management promote good seed emergence in tomatoes-Schwankl, Grattan, Miyao Nov-Dec 21

If registered, fungicide would reduce cavity spot in carrots - Davis et al. Mar-Apr 29

Low-input management of weeds in vegetable fields - Lanini, Le Strange Jan-Feb 11

New strain of sweetpotato whitefly invades California vegetables Perring et al. Nov-Dec 10

\section{EDITORIALS}

Natural Reserve System: Putting the "Nature" in "Natural Resources" Farrell Jan-Feb

Publicly funded agricultural research: an impending crisis? - Farrell MarApr

Water scarcity: the changing California water scene - Farrell May-Jun

Pest management: the search for alternatives - Farrell Jul-Aug

North American free trade: a strategy for California agriculture - Farrell Sep-Oct

Public literacy about agriculture: What is it? What is it for? - King NovDec 